\title{
Nutritional regulators of the hypothalamic-pituitary axis in pigs
}

\author{
C. R. Barb ${ }^{1}$, R. R. Kraeling ${ }^{1}$ and G. B. Rampacek ${ }^{2}$ \\ 'Animal Physiology Research Unit, USDAVARS, Richard B. Russell Agriculture Research Center, \\ PO Box 5677, Athens, GA 30604, USA; and ${ }^{2}$ Animal and Dairy Science Department, \\ University of Georgia, Athens, GA 30602, USA
}

\begin{abstract}
Nutritional signals are detected by the central nervous system (CNS) and translated by the neuroendocrine system into signals that alter secretion of LH and growth hormone $(\mathrm{GH})$. Furthermore, these signals directly affect the activity of the pituitary gland independently of CNS input. Insulin-like growth factor I (IGF-I), insulin, leptin and specific metabolites, such as glucose and free fatty acids (FFA)', are potential signals of the metabolic status to the brain-pituitary axis. Intravenous injection of a lipid emulsion or glucose suppressed the $\mathrm{GH}$ and $\mathrm{LH}$ response to $\mathrm{GH}$ releasing hormone $(\mathrm{GHRH})$ and $\mathrm{GnRH}$, respectively. Insulin and IGF-I regulation of $\mathrm{LH}$ and $\mathrm{GH}$ secretion occur at the pituitary gland. Feed deprivation for $24 \mathrm{~h}$ suppressed leptin secretion without affecting $\mathrm{LH}$ or $\mathrm{GH}$ secretion, whereas central administration of leptin resulted in a decrease in feed intake and an increase in $\mathrm{CH}$ secretion. Oestrogen-induced leptin gene expression in adipose tissue increased with age and adiposity in pigs. Leptin stimulated GnRH release from hypothalamic tissue in vitro. These results identify putative signals that link metabolic status and neuroendocrine control of growth and reproduction by altering endocrine function during periods of fasting, feed restriction and lactation.
\end{abstract}

\section{Neuroendocrine control of $\mathrm{LH}$ and $\mathrm{GH}$ secretion}

It is generally accepted that there are two modes of $\mathrm{LH}$ secretion in pigs (Kraeling and Barb, 1990): pulsatile secretion and surge secretion. These patterns of LH secretion reflect the pattern of GnRH released from neurosecretory neurones within the hypothalamus into the hypothalamic-hypophysial portal system (Goodman, 1988). An LH pulse and an LH surge generator are located within the CNS of pigs (Kraeling and Barb, 1990). The importance of pulsatile $\mathrm{GnRH}$ and $\mathrm{LH}$ secretion was demonstrated by Lutz et al. (1984) and Pressing et al. (1992) who induced precocious oestrus and ovulation in intact prepubertal gilts by giving i.v. injections of $\mathrm{GnRH}$ at $1 \mathrm{~h}$ intervals. In addition, administration of $\mathrm{GnRH}$ at $1 \mathrm{~h}$ intervals to anoestrous postpartum sows induced oestrus and ovulation (Cox and Britt, 1988). Wetsel et al. (1992) reported intrinsic pulsatile secretory activity of immortalized $\mathrm{GnRH}$ neurones in vitro. Thus, GnRH neurones secrete their product in an autonomous episodic frequency, but interoceptive and exteroceptive factors detected by the CNS are translated by the 
neuroendocrine system into signals that alter the pattern of $\mathrm{GnRH}$ and subsequent $\mathrm{LH}$ secretion. For example, interoceptive signals, such as gonadal and adrenal steroids, metabolites, and other neuronal signals, act to modulate pulse frequency and amplitude of $\mathrm{GnRH}$ pulses.

Many of the interoceptive signals that regulate $\mathrm{GnRH}$ and $\mathrm{LH}$ secretion also modulate $\mathrm{GH}$ secretion. Of particular importance is the role of nutrition and metabolic status in maintaining reproductive function, but also in modulating the $\mathrm{GH}$-releasing hormone (GHRH)somatostatin-GH axis and subsequent growth. It is well established that the onset of puberty is linked to the attainment of a critical body weight or metabolic mass, indicating an association between mechanisms regulating energy balance and the reproductive and growth axis.

\section{Metabolism and the endocrine system}

The importance of nutrition and metabolic state in maintaining reproductive function is well established. The onset of puberty may be linked to attainment of a critical body weight or a minimum percentage of body fat (Frisch, 1984). Alternatively, metabolic mass and food intake, or its correlated metabolic rate, may be the triggering mechanism (Frisch, 1984). Cameron et al. (1985) reported that transition from a fed to a fasting state occurred more rapidly in the juvenile than in the mature monkey. Cameron et al. (1985) suggested that the dynamic fluctuations in plasma hormones and substrates that occur during postprandial and postabsorptive periods provide signals to the brain that link metabolic status to activation of the reproductive system. Nutritional perturbations delay the onset of puberty, interfere with normal oestrous cycles and alter LH secretion in pigs (for a review, see Prunier and Quesnel, 2000a).

The GH response to nutritional status is variable in pigs. Buonomo et al. (1988) reported that serum $\mathrm{GH}$ concentrations increased after $48 \mathrm{~h}$ of fasting in barrows. In contrast, Booth (1990) reported that feed restriction for 8-14 days failed to affect serum $\mathrm{GH}$ concentrations in prepubertal gilts. Acute feed deprivation failed to influence $\mathrm{GH}$ secretion during a $28 \mathrm{~h}$ fast, although serum GH secretion increased after feeding was resumed. Similarly, Armstrong and Britt (1987) reported that $\mathrm{GH}$ secretion increased during the postprandial period in feed restricted gilts. However, antagonism of glucose utilization increased basal and mean serum $\mathrm{GH}$ concentrations, but not $\mathrm{GH}$ pulse frequency and amplitude (Barb et al., 2001). Thus, GH response to energy availability is equivocal.

Collectively, these data demonstrate that nutritional status affects endocrine function. Contemporary models of energy regulation emphasize physiological signals that control energy intake, partitioning and expenditure, and their sites of action. It is hypothesized that mechanisms regulating energy balance are sensitive to metabolic signals generated by changes in oxidation of metabolic fuels and could account for positive correlations between body fat, fertility and endocrine function (Wade et al., 1996). Identification of specific metabolic signals that influence the reproductive and growth axis remains elusive, primarily because of the large number of substances from the periphery that may act centrally to modify neuronal activity. Similar to the study by Cameron et al. (1985) on primates, Barb et al. (1997) reported that transition from a fed to fasting state occurred more rapidly in prepubertal than in mature gilts. Different temporal relationships between circulating blood concentrations of glucose, free fatty acids (FFA), ketones, insulin and IGF-I in mature and prepubertal pigs were probably related to a greater glucose production rate, higher metabolic rate, smaller energy reserves and greater growth requirements in prepubertal gilts. In a subsequent study, acute fasting suppressed leptin secretion in prepubertal gilts (Barb et al., 2001). Thus, glucose, FFA, IGF-I, insulin and leptin may provide peripheral signals to the brain that link metabolic status 
to activation of the reproductive system and modulation of the growth axis. The intent of this review is to present evidence for nutritional control of the hypothalamic-pituitary axis and putative sites of action of specific metabolites and metabolic hormones in modulating $\mathrm{LH}$ and $\mathrm{GH}$ secretion. The effects of nutrition and feed restriction on reproductive function in pigs will not be discussed. For further information on nutrition and reproductive function in pigs see Cosgrove and Foxcroft (1996) and Prunier and Quesnel (2000a,b).

\section{Nutritional mediators of LH and GH secretion}

\section{Roles of glucose and insulin}

Numerous reports have led to the proposal that blood glucose concentration is an accurate reflection and index of the collective effects of energy on reproduction and growth. Moreover, changes in gluconeogenesis may be the mechanism by which altered energy metabolism affects the neuroendocrine axis in pigs. In support of this idea, Barb et al. (1997) suggested that the ability of pigs to maintain euglycaemia during acute fasting was primarily due to rapid mobilization of alternative energy stores, such as FFA. This mobilization of energy stores may account for the failure of acute feed deprivation to affect LH secretion. Booth (1990) demonstrated that administration of glucose to feed-restricted gilts induced a rapid increase in episodic LH secretion similar to that observed in response to resumed feeding. In contrast, the $\mathrm{LH}$ response to $\mathrm{GnRH}$ was lower in satiated prepubertal gilts that received an i.v. injection of glucose compared with that of saline-treated gilts (Barb et al., 1991). These conflicting results may, in part, be related to nutritional state, which has a profound effect on circulating concentrations of metabolites and metabolic hormones. These factors could alter the hypothalamic-pituitary response to glucose challenge.

Blocking of glycolysis with 2-deoxy-D-glucose resulted in a marked reduction in LH pulse frequency and an increase in serum $\mathrm{GH}$ concentrations in prepubertal gilts (Barb et al., 2001). Furthermore, an i.v. bolus of glucose suppressed the $\mathrm{GH}$ response to $\mathrm{GHRH}$ in gilts (Barb et


suppressed the $\mathrm{LH}$ and $\mathrm{GH}$ responses to $\mathrm{GnRH}$ and $\mathrm{GHRH}$, respectively (Barb et al., 1995; Tables 1 and 2). The above studies support the hypothesis that glucose is a primary regulator of $\mathrm{LH}$ and $\mathrm{GH}$ secretion, and that the pituitary gland is a potential site of action.

The physiological relevance of the decrease in serum insulin concentrations during fasting is not clear (Barb et al., 1997). In primiparous lactating sows (Rojkittikhun et al., 1993a) and prepubertal gilts (Barb et al., 2001), a $24 \mathrm{~h}$ fast did not affect $\mathrm{LH}$ secretion, although serum insulin concentrations were suppressed compared with those of animals that were fed. Increased dietary energy and insulin treatment in gilts at the follicular phase resulted in an increase in serum LH and FSH concentrations, but this effect did not occur in the absence of increased dietary energy (Cox et al., 1987). Rojkittikhun et al. (1993b) reported that insulin treatment increased plasma $\mathrm{LH}$ concentrations but did not affect $\mathrm{LH}$ pulse frequency during the weaning to oestrus interval in primiparous sows. One model used to study the effect of insulin on the hypothalamic-pituitary axis is the diabetes-induced animal. In diabetic ovariectomized gilts, withdrawal of insulin therapy for 4 days prevented the oestradiol-induced preovulatory-like LH surge, but did not affect pulsatile $\mathrm{LH}$ secretion (Angell et al., 1996). This finding indicates that diabetes mellitus alters the sensitivity of the hypothalamic-pituitary axis to oestradiol and the responsiveness of the pituitary gland to GnRH. Pituitary cell culture experiments confirmed that the sensitivity of the pituitary gland to $\mathrm{GnRH}$ decreased after removal of insulin therapy for 7 days in diabetic pigs (Angell et al., 1996; Table 1). 


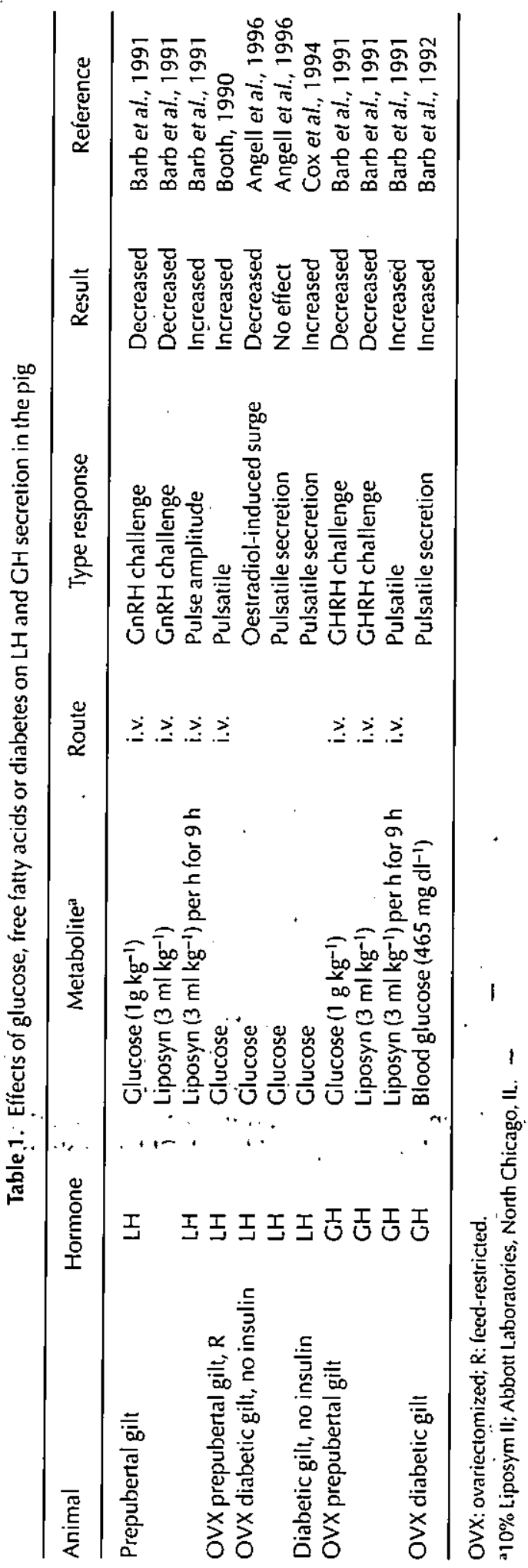


Table 2. Effects of glucose, oleic or linoleic acids on basal, GnRH and GHRH-induced LH and GH secretion from anterior pituitary cells in culture from prepubertal gilts ${ }^{\mathrm{a}}$

\begin{tabular}{|c|c|c|c|c|}
\hline & Hormone & Metabolite & Dose & Result \\
\hline \multicolumn{5}{|l|}{ Basal secretion } \\
\hline & LH & Glucose & $300,600 \mathrm{mg} \mathrm{dl}^{-1}$ & No effect \\
\hline & $\mathrm{GH}$ & Glucose & $100,300,600 \mathrm{mg} \mathrm{dl}^{-1}$ & No effect \\
\hline & $\mathrm{LH}$ & Oleic acid & $10^{-7}, 10^{-6}, 10^{-5}, 10^{-4} \mathrm{moll}^{-1}$ & Increased \\
\hline & LH & Linọleic acid & $10^{-6}, 10^{-5}, 10^{-4} \mathrm{~mol} \mathrm{I}^{-1}$ & Increased \\
\hline & $\mathrm{GH}$ & Oleic acid & $10^{-11}, 10^{-9} \mathrm{~mol} \mathrm{I}^{-1}$ & Decreased \\
\hline & & & $10^{-7}, 10^{-5} \mathrm{moll}^{-1}$ & Increased \\
\hline & $\mathrm{GH}$ & Linoleic acid & $10^{-9} \mathrm{moll}^{-1}$ & Increased \\
\hline \multicolumn{5}{|l|}{ Response to $\mathrm{GnRH}$} \\
\hline & LH & Glucose & $600 \mathrm{mg} \mathrm{dl}^{-1}$ & Decreased \\
\hline & $\mathrm{LH}$ & Oleic acid & $10^{-6}, 10^{-5}, 10^{-4} \mathrm{moll}^{-1}$ & Decreased \\
\hline & $\mathrm{LH}$ & Linoleic acid & $10^{-5} \mathrm{moll}^{-1}$ & Decreased \\
\hline \multicolumn{5}{|l|}{ Response to GHRH } \\
\hline & $\mathrm{GH}$ & Glucose & $100,300,600 \mathrm{mg} \mathrm{dl}^{-1}$ & Decreased \\
\hline & $\mathrm{GH}$ & Oleic acid & $10^{-11}, 10^{-9}, 10^{-7}, 10^{-5} \mathrm{moll}^{-1}$ & Decreased \\
\hline & $\mathrm{GH}$ & Linoleic acid & $10^{-11}, 10^{-9}, 10^{-7}, 10^{-5} \mathrm{~mol} \mathrm{l-1}$ & Decreased \\
\hline
\end{tabular}

'From Barb et al. (1995).

Mean serum $\mathrm{GH}$ concentrations and $\mathrm{GH}$ pulse frequency were greater in gilts with poorly controlled diabetes than in control pigs. Serum insulin concentrations were lower $(0.3 \pm 0.02$ versus $0.9 \pm 0.05 \mathrm{ng} \mathrm{ml}^{-1} ; P<0.0001$ ) and plasma glucose concentrations were higher $\left(465 \pm 17\right.$ versus $\left.82 \pm 17 \mathrm{mg} \mathrm{dl}^{-1} ; P<0.05\right)$ in diabetic pigs than in control pigs (Barb et al., 1992). The increase in GH secretion may be due, in part, to higher $(P<0.0002)$ glucose concentrations in the cerebrospinal fluid of diabetic pigs (162 $\pm 14 \mathrm{mg} \mathrm{dl}^{-1}$ ) compared with control pigs $\left(51 \pm 3 \mathrm{mg} \mathrm{dl}^{-1}\right)$, which alters $\mathrm{GHRH}$ and somatostatin secretion from the hypothalamus, which in turn alters pituitary somatotrope activity (Barb et al., 1992).

Two studies were conducted to investigate the-idea that insulin acts at either the CNS or pituitary gland to alter $\mathrm{LH}$ and $\mathrm{GH}$ secretion. Central administration of insulin at doses of $1-100 \mu \mathrm{g}$ failed to change $\mathrm{LH}$ and $\mathrm{GH}$ secretion in ovariectomized prepubertal gilts (Barb et al., 1996; Fig. 1). However, insulin suppressed basal $\mathrm{GH}$ secretion and the $\mathrm{GH}$ response to GHRH for anterior pituitary cells in culture from 180-day-old gilts (C. R. Barb, ). B. Barrett and R. R. Kraeling, unpublished; Fig. 2). Thus, the influence of insulin on the LH and GH axis appears to be a manifestation of plasma glucose concentration. However, subtle effects of insulin on the sensitivity of the pituitary gland to hypothalamic secretagogues cannot be discounted (Tables 3 and 4 ).

\section{Role of FFA}

In pigs, feed deprivation results in a rapid onset of FFA mobilization from peripheral fat deposits, but maintenance of euglycaemia indicates an increase in hydrolysis of triglycerides and FFA oxidation resulting in glucose sparing (Barb et al., 1997). Armstrong and Britt (1987) reported that chronic feed restriction in gilts resulted in cessation of oestrous cycles and lower concentrations of plasma insulin, increased concentrations of FFA and reduced LH pulse 

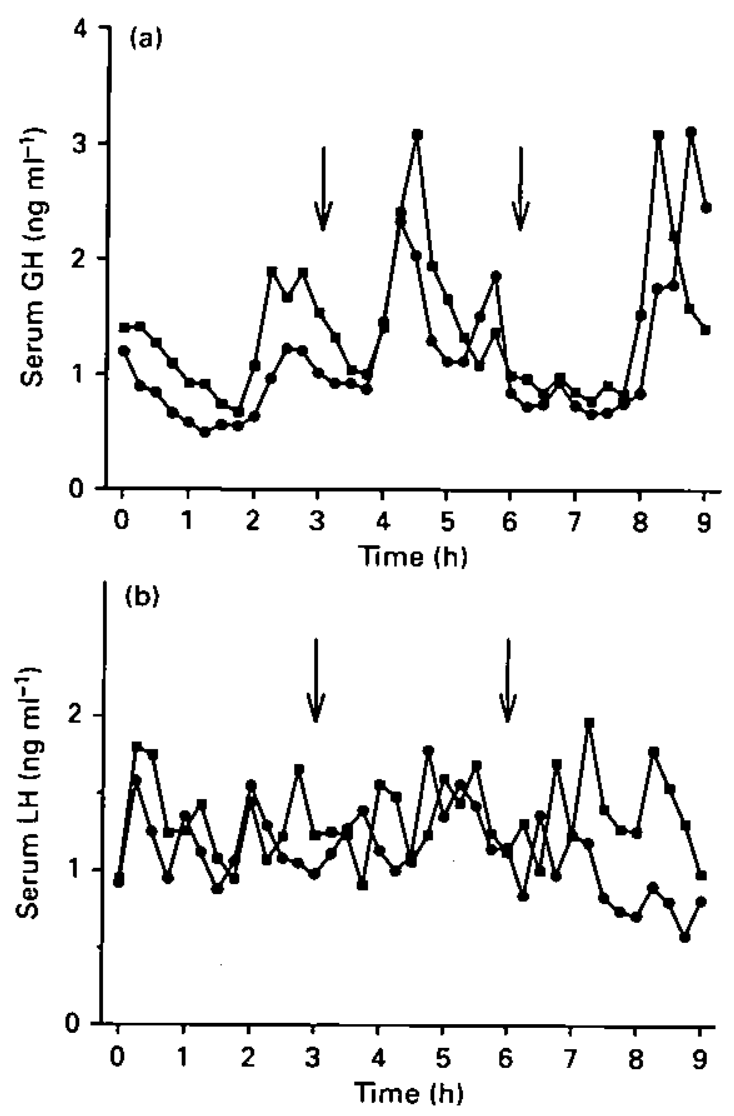

Fig. 1. Concentrations of serum (a) $\mathrm{GH}$ and (b) LH in ovariectomized prepubertal gilts receiving intracerebroventricular injection of saline $(\boldsymbol{Q} ; n=4)$ or $1 \mu \mathrm{g}$ insulin $(0 ; n=4)$ at $3 \mathrm{~h}$ and $6 \mathrm{~h}$ (arrows). Pooled standard errors for $\mathrm{LH}=0.2 \mathrm{ng} \mathrm{ml}^{-1}$ and $\mathrm{GH}=0.5 \mathrm{ng} \mathrm{m}^{-1}$.

frequency compared with those of control gilts. Booth (1990) reported similar results in prepubertal gilts that were feed-restricted for 8 days, whereas in prepubertal gilts subjected to short-term fasting, serum concentrations of FFA increased, but there was no change in LH or $\mathrm{CH}$ secretion compared with control gilts (Barb et al., 2001). In primiparous lactating sows, concentrations of serum FFA increased on day 12 and day 20 of lactation and this was associated with increased fat mobilization and protein catabolism (Armstrong et al., 1986). Sows that remained anoestrous after weaning had increased plasma glucose concentrations and lower serum concentrations of FFA on day 12 and day 20 than those of oestrous sows. The authors speculated that aberrations in energy metabolism during lactation might have predisposed sows to anoestrus after weaning.

Therefore, do alterations in serum concentrations of FFA influence hypothalamic-pituitary function? In prepubertal gilts, i.v. infusion of a lipid emulsion enhanced the $\mathrm{LH}$ response to 


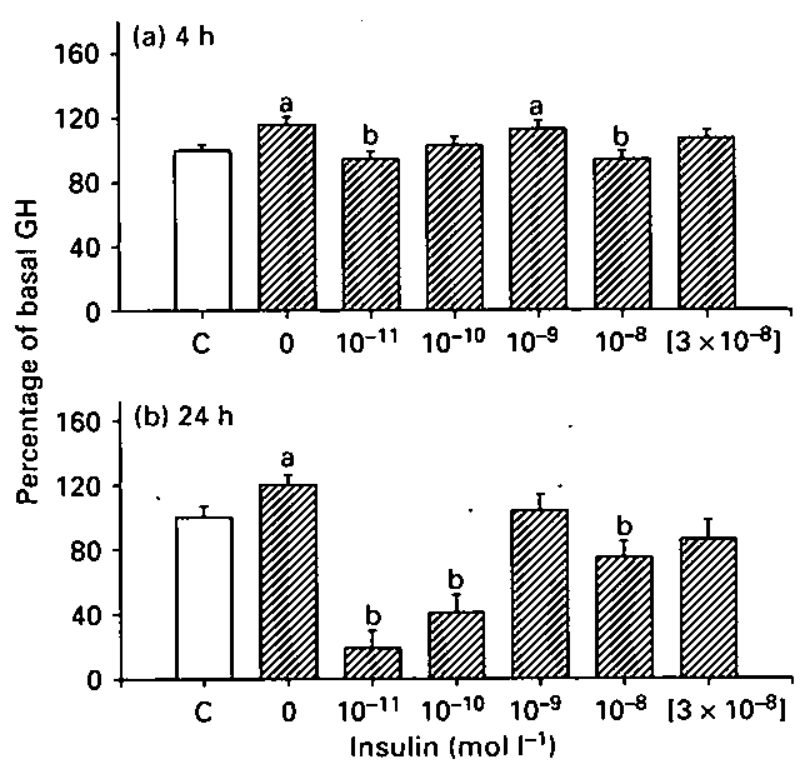

Fig. 2. Effect of insulin $\left(0-3 \times 10^{-8} \mathrm{~mol}^{-1}\right)$ on growth hormone-releasing hormone (GHRH)-induced $\left(10^{-6} \mathrm{~mol} \mathrm{I}^{-1}\right)$ $\mathrm{GH}$ secretion in pig pituitary cells during (a) $4 \mathrm{~h}$ or (b) $24 \mathrm{~h}$ culture periods. Values are mean \pm standard errors $(n=8-12$ wells per treatment). C: control = basal secretion in the absence of treatment. aSignificantly different from the control $(P<0.05)$. bSignificantly different from $\mathrm{GHRH}$ alone $(P<0.05)$.

$\mathrm{GnRH}$, but suppressed the $\mathrm{GH}$ response to $\mathrm{GHRH}$, whereas infusion of the lipid emulsion at $1 \mathrm{~h}$ intervals increased serum $\mathrm{LH}$ pulse amplitude and $\mathrm{GH}$ pulse frequency (Barb et al., 1991; Table 1). The hourly fluctuations in serum concentrations of FFA may have synchronized the endogenous rhythm of GHRH and somatostatin secretion from the hypothalamus and, subsequently, altered somatotrope activity. Cultured pig pituitary cells were used to determine whether the effects of FFA in vivo occur at the pituitary gland without benefit of CNS input. Oleic and linoleic acids increased basal $\mathrm{LH}$ release. In contrast, oleic acid suppressed $\mathrm{GnRH}$ induced release of $\mathrm{LH}$ (Table 2). This response was equivocal for linoleic acid (Barb et al., 1995). It is difficult to explain the differences between the in vivo and in vitro results. One possibility is that other hypothalamic factors in vivo may have altered pituitary gland responsiveness to $\mathrm{GnRH}$ (Barb et al., 1991). Alternatively, the lipid emulsion infused in the in vivo study (Barb et al., 1991) consisted of linoleic, oleic, palmitic, linolenic and stearic acids, whereas the effects of oleic or linoleic acid alone were evaluated in the in vitro study (Barb et al., 1995). Oleic and linoleic acids act directly on the anterior pituitary cells to alter basal and GHRH-induced GH release (Barb et al., 1995; Table 2). Moreover, this event seems to be mediated at the plasma membrane, because oleic and linoleic acids do not block the forskolin-induced release of $\mathrm{GH}$ (Barb et al., 1995). Thus, the above findings may explain, in part, the altered neuroendocrine activity observed during periods of fasting, feed restriction and lactation. 


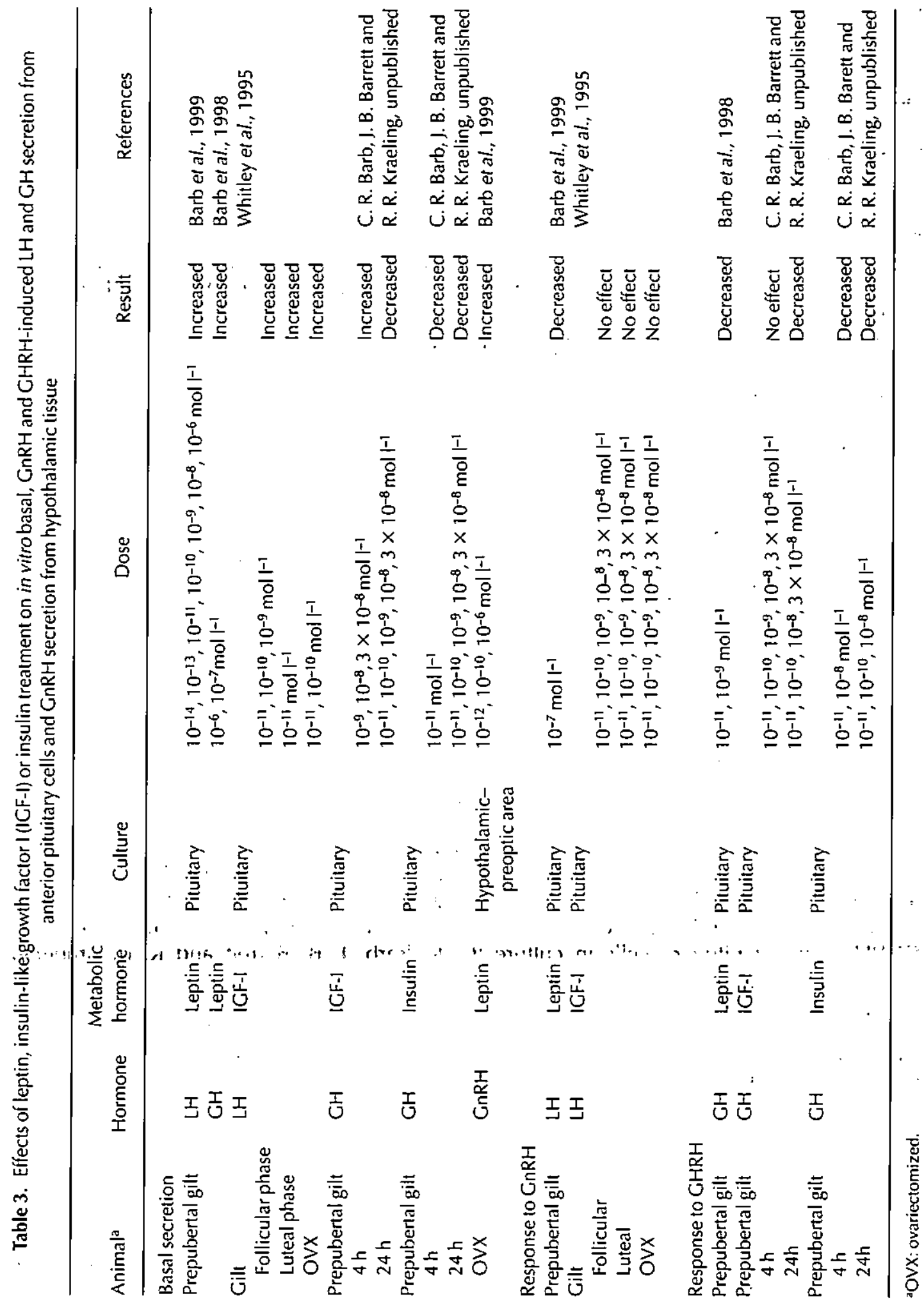


Role of IGF-I

IGF-I appears particularly suitable for a role in linking somatic growth and development to activation of the reproductive axis. IGF-I exerts neurotrophic and mitogenic effects in the brain via interaction with specific receptors (Sara and Hall, 1990). Although type I IGF receptors are distributed widely throughout the brain, they are more concentrated in the median eminence (Werther et al., 1990) indicating that, in this region, IGF-I is involved in functions other than cellular differentiation. Although IGF-I concentrations in the postnatal hypothalamus appear to be independent of peripheral concentrations (Rotwein et al., 1988), circulating concentrations of IGF-I increased during pubertal development in pigs (Lee et al., 1991). It is now clear that the peripubertal increase in serum IGF-I concentration is from hypothalamic, hepatic (Handelsman et al., 1987) and adipose tissue (Wolverton et al., 1992). Moreover, the pubertal increase in circulating IGF-I concentrations (Lee et al., 1991) occurs concomitantly with an age-related decrease in pituitary response to GHRH (Dubreuil et al., 1987) and an increase in LH secretion (Lutz et al., 1984). These observations indicate that IGF-I may modulate hypothalamic release of $\mathrm{GnRH}$ and $\mathrm{GHRH}-$ somatostatin and pituitary responsiveness to hypothalamic hormones.

It is proposed that IGF-l acts, in a feedback loop, directly on the pituitary gland and brain to regulate $\mathrm{LH}$ and $\mathrm{GH}$ secretion. Although most evidence indicates that the effect of IGF-I on the release of pituitary hormones occurs in the CNS, subtle effects on the anterior pituitary cannot be discounted. Hiney et al. (1991) reported that IGF-I elicited GnRH release from the median eminence in vitro. The release of $\mathrm{GnRH}$ is greater after IGF-I than after IGF-II or insulin administration, indicating that IGF-I is the primary signal (Hiney et al., 1991). In addition, release of $\mathrm{GnRH}$ from the median eminence, which is devoid of $\mathrm{GnRH}$ cell bodies, indicates that activation of gene expression by IGF-I is not involved. In rats, intracerebroventricular administration of IGF-I suppressed pulsatile $\mathrm{GH}$ secretion and stimulated brain somatostatin release (Abe et al., 1983). IGF-l inhibited both acute release of $\mathrm{GH}$ and $\mathrm{GH}$ mRNA content in rat pituitary cells in vitro (Yamashita and Melmed, 1986). Moreover, intracerebroventricular administration of IGF-I suppressed $\mathrm{GH}$ secretion in pig fetuses (Spencer et al., 1991; Table 4). In a recent experiment, intracerebroventricular administration of $10 \mu \mathrm{g}$ IGF-I failed to alter $\mathrm{LH}$ and $\mathrm{GH}$ secretion in ovariectomized prepubertal gilts. Mean serum $\mathrm{LH}$ and $\mathrm{GH}$ concentrations before treatment were $0.8 \pm 0.2$ and $1.7 \pm 0.6 \mathrm{ng} \mathrm{ml}^{-1}$ and after treatment were $1.0 \pm 0.2$ and $1.7 \pm 0.6 \mathrm{ng} \mathrm{ml}^{-1}$, respectively (Barb et al., 1996). Doses up to $75 \mu \mathrm{g}$ ICF-I failed to alter $\mathrm{LH}$ and $\mathrm{GH}$ secretion (Barb et al., 1996). IGF-I suppressed basal GH secretion (Table 3) and the GH response to GHRH from pig pituitary cells in culture (C. R. Barb, J. B. Barrett and R. R. Kraeling, unpublished; Fig. 3). Furthermore, Whitley et al. (1995) reported that IGF-I-induced $\mathrm{LH}$ secretion was greater in pituitary cells from gilts at the follicular phase compared with cells from gilts at the luteal phase and ovariectomized gilts (Table 3). Thus, under certain physiological conditions, such as steroid milieu or nutritional status, endogenous IGF-I may contribute to the regulation of $\mathrm{LH}$ and $\mathrm{GH}$ secretion from the anterior pituitary in pigs.

\section{Role of leptin}

Leptin, secreted by adipose tissue in response to changes in energy availability, serves as a circulating signal of nutritional status and has a profound influence on regulation of the neuroendocrine axis and appetite in rodents (Casanueva and Dieguez, 1999; Ahima and Flier, 
Table 4: Effects of leptin, insulin-like growth factor $1(\mathrm{IGF}-1)$ or insulin treatment on $\mathrm{LH}$ and $\mathrm{GH}$ secretion in vivo

\begin{tabular}{|c|c|c|c|c|c|}
\hline Animal & Hormone & Hormone and dose & Route & Results & References \\
\hline Prepubertal gilt & $\begin{array}{l}\mathrm{LH} \\
\mathrm{GH}\end{array}$ & $\begin{array}{l}\text { Leptin: } 10,50 \text { or } 100 \mathrm{~g} \\
\text { Leptin: } 10,50 \text { or } 100 \mathrm{~g}\end{array}$ & $\begin{array}{l}\text { ICV } \\
\text { ICV }\end{array}$ & $\begin{array}{l}\text { No effect } \\
\text { Increased }\end{array}$ & $\begin{array}{l}\text { Barb et al., } 1999 \\
\text { Barb et al., } 1998\end{array}$ \\
\hline & $\mathrm{GH}$ & IGF-I: $0.1,1,10,25$ or $75 \mathrm{~g}$ & $\mathrm{ICV}$ & No effect & Barb etal., 1996 \\
\hline Fetal pig & $\mathrm{CH}$ & IGF-I: $1.5 \mathrm{~g}$ & ICV & Decreased & Spencer et al:, 1991 \\
\hline OVX prepubertal & $\mathrm{LH}$ & $\begin{array}{l}\text { Insulin: } 1,10 \text { or } 100 \mathrm{~g} \\
\text { Insulin: } 1,10 \text { or } 100 \mathrm{~g}\end{array}$ & $\begin{array}{l}\text { ICV } \\
\text { ICV }\end{array}$ & No effect & Barb et al., 1996 \\
\hline OVX gilt & $\mathrm{LH}$ & $\begin{array}{l}\text { Insulin: } 6 \mathrm{ng} \\
\text { Insulin: } 3,6 \text { or } 12 \mathrm{ng}\end{array}$ & $\begin{array}{l}\text { ICV } \\
\text { ICV }\end{array}$ & Increased & Cox et al., 1990 \\
\hline OVX gilt & $\mathrm{GH}$ & Insulin: 3,6 or $12 \mathrm{ng}$ & ICV & No effect & Barb et al., 1990 \\
\hline Postpartum sow & LH & Insulin: $0.5 \mathrm{iu} \mathrm{kg}^{-1}$ body weight & i.v. & No effect & Rojkittikhun et al., 1993b \\
\hline Gilt follicular phase & LH & $\begin{array}{l}\text { Insulin: } 0.1 \text { iu } \mathrm{kg}^{-1} \text { body weight } 4 \times \text { day }+9,960 \mathrm{kcal} \mathrm{Me} \mathrm{day}^{-1} \\
\text { Insulin: } 0.1 \text { iu } \mathrm{kg}^{-1} \text { body weight } 4 \times \text { day }+5,771 \mathrm{kcal} \mathrm{Me} \mathrm{day-1}^{-1}\end{array}$ & $\begin{array}{l}\text { i.v. } \\
\text { i.v. }\end{array}$ & $\begin{array}{l}\text { Increased } \\
\text { No effect }\end{array}$ & $\begin{array}{l}\text { Cox et al., } 1987 \\
\text { Cox et al. } 1987\end{array}$ \\
\hline
\end{tabular}

OVX: ovariectomized; Me: metabolizable energy; ICV: intracerebroventricular. 


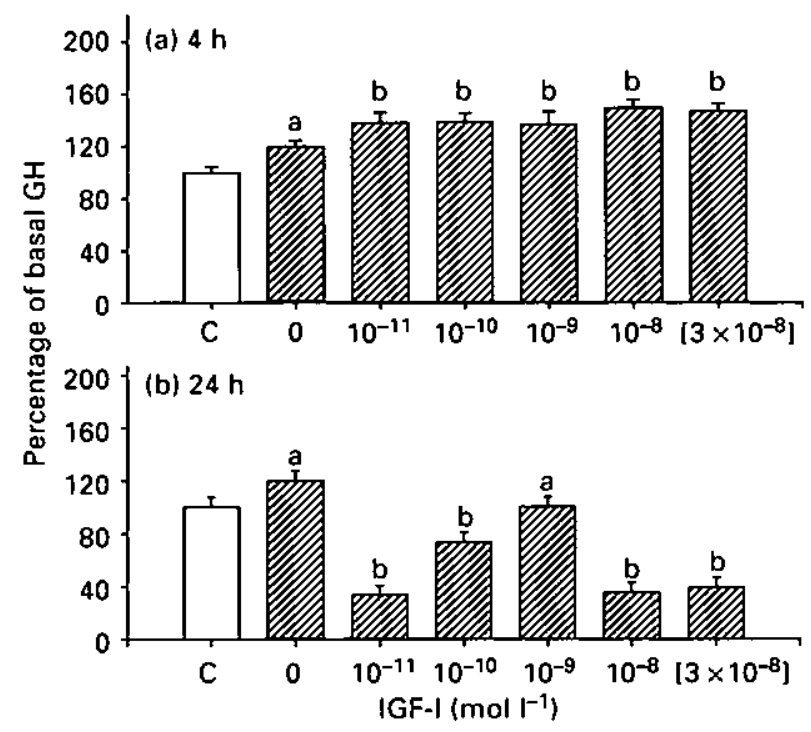

Fig. 3. Effect of insulin-like growth factor I (IGF-I) $\left(0-3 \times 10^{-8} \mathrm{~mol}^{-1}\right)$ on growth hormone-releasing hormone $(\mathrm{GHRH})$-induced $\left(10^{-6} \mathrm{~mol}^{-1}\right) \mathrm{GH}$ secretion in pig pituitary cells during (a) $4 \mathrm{~h}$ or (b) $24 \mathrm{~h}$ culture periods. Values are mean \pm standard errors ( $n=8-12$ wells per treatment). $C:$ control $=$ basal secretion in the absence of treatment. aSignificantly different from the control $(P<0.05)$. bSignificantly different from $\mathrm{GHRH}$ alone $(P<0.05)$.

2000). We reported that serum leptin concentrations increased with age (Qian et al., 1999) and decreased in response to feed deprivation (Barb et al., 2001). In the ovariectomized prepubertal gilt, oestrogen-induced leptin mRNA expression in adipose tissue occurred at the time of expected puberty in intact gilts (Qian et al., 1999) and was associated with greater LH secretion (Barb et al., 2000). Furthermore, expression of the long form leptin receptor (OB-Rl) mRNA in the hypothalamus had increased by 3.5 months of age and remained high at 6 months of age in the prepubertal gilt demonstrating an age-dependent increase in OB-RI expression (Lin et al., 2001). Thus, leptin may be an important link between metabolic status and the neuroendocrine system.

Gonadotrophin secretion. The multifaceted effects of leptin appear to be mediated by the hypothalamus. In pigs, the presence of biologically active leptin receptors in the hypothalamus and pituitary gland indicate that leptin acts through the hypothalamic-pituitary axis (Lin et al., 2000). In support of this proposal, leptin increased LH secretion from pig pituitary cells in vitro and $\mathrm{GnRH}$ release from hypothalamic tissue in vitro (Barb et al., 1999; Table 3). Co-localization of leptin receptor mRNA with neuropeptide Y (NPY) gene expression provides strong evidence that hypothalamic NPY is a potential target for leptin (Cunningham et al., 1999). In pigs, central administration of NPY suppressed LH secretion (Barb, 1999). However, fertility was restored only partially in the ob/ob mouse with a homozygous null mutation for NPY (Erickson et al., 1996). In addition, leptin failed to affect in vitro NPY release from pig hypothalamic-preoptic area tissue fragments (C. R. Barb, unpublished). Therefore, 
the action of leptin at the CNS may be mediated via other hypothalamic factors in addition to NPY.

Growth hormone axis. Growth hormone, unlike other pituitary hormones, exerts biological effects on most tissues in the body and plays an important role in the regulation of metabolism and energy balance (Etherton and Bauman, 1998). Altered GH secretion is associated with changes in body composition, metabolism and fasting (Muller et al., 1999). A common factor associated with all of the above situations is a change in adiposity or change in energy metabolism.

We assessed the role of leptin in modulating $\mathrm{GH}$ secretion by intracerebroventricular administration of leptin to pigs that had been fed. $\mathrm{GH}$ secretion increased markedly in pigs that were fed normally, and maximum concentrations of $\mathrm{GH}$ occurred at 15-30 min after intracerebroventricular injection (Barb et al., 1998), which is similar to the $\mathrm{GH}$ response to exogenously administered GHRF (Barb et al., 1991; Table 4). More-over, central administration of leptin reduced feed intake in a dose-dependent manner and this effect was still apparent at $48 \mathrm{~h}$ after leptin treatment (Barb et al., 1998). In addition to a hypothalamic site of action, we demonstrated that leptin stimulated basal $\mathrm{GH}$ secretion and inhibited GHRH-induced GH secretion from pituitary cells in culture (Barb et al., 1998; Table 3). Taken together, these results support the hypothesis that adipose tissue secretes a protein signal that acts on the CNS to regulate $\mathrm{GH}$ secretion and feed intake.

Leptin, a metabolic signal, regulates $L H$ and $G H$ secretion. In pigs, pulsatile leptin secretion decreased significantly after $24 \mathrm{~h}$ of a $28 \mathrm{~h}$ fast with no subsequent change in $\mathrm{LH}$ and $\mathrm{GH}$ secretion or in subcutaneous back fat thickness. However, plasma glucose and serum insulin and IGF-I concentrations were lower in fasted animals compared with control animals (Barb et al., 2001). Prepubertal gilts were treated with 2-deoxy-D-glucose, a competitive inhibitor of glycolysis, to determine whether the effects of metabolic fuel restriction on $\mathrm{LH}$ and $\mathrm{GH}$ secretion were due to reduced serum leptin concentrations. Treatment with 2-deoxy-Dglucose increased mean serum $\mathrm{GH}$ concentrations, but failed to affect the frequency and amplitude of $\mathrm{GH}$ pulses. However, 2-deoxy-D-glucose suppressed LH pulse frequency, but failed to alter mean serum LH concentrations and LH pulse amplitude. Serum leptin concentrations were unchanged by 2-deoxy-D-glucose treatment (Barb et al., 2001). These results indicate that acute effects of energy deprivation on $\mathrm{LH}$ and $\mathrm{GH}$ secretion are independent of changes in serum leptin concentrations and that there are two distinct sites at which leptin and glucose modulate the neuroendocrine axis.

\section{Conclusion}

Evidence has been presented that supports the concept that metabolites and metabolic hormones affect both hypothalamic hormone secretion and, hence, anterior pituitary function and anterior pituitary hormone secretion, directly. In general, glucose, FFA, insulin and IGF-I act primarily at the anterior pituitary gland to modulate pituitary responsiveness to $\mathrm{GHRH}$ and $\mathrm{GnRH}$, whereas there are two distinct sites of action for leptin in regulating $\mathrm{LH}$ and $\mathrm{GH}$ secretion. Although leptin is an important metabolic signal, other metabolic cues, such as glucose, FFA, insulin and IGF-I, may play a role in modulating the neuroendocrine axis during pubertal development, lactation and during periods of acute and chronic undernutrition (Fig. 4). 


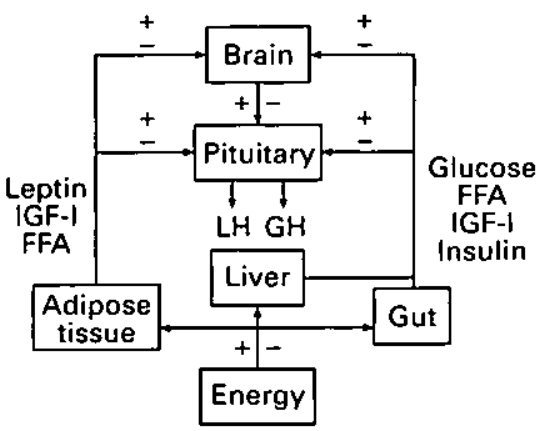

Fig. 4. Putative sites of action for metabolic fuels and metabolic hormones in neuroendocrine control of $\mathrm{LH}$ and $\mathrm{CH}$ secretion in pigs. Changes in circulating concentrations of glucose, free fatty acids (FFA), insulin, insulin-like growth factor $I$ (IGF-1) and leptin in response to energy availability can be both inhibitory and stimulatory to $\mathrm{LH}$ and $\mathrm{CH}$ secretion.

\section{References}

Abe H, Molitch ME, Van Wyk II and Underwood LE (1983) Human growth hormone and somatomedin $C$ suppress the spontaneous release of growth hormone in unanesthetized rats Endocrinology 113 1319-1324

Ahima RS and Flier IS (2000) Leptin Annual Review of Physiology 62 413-437

Angell CA, Tubbs RC, Moore AB, Barb CR and Cox NM (1996) Depressed luteinizing hormone response to estradiol in vivo and gonadotropin-releasing hormone in vitro in experimentally diabetic swine Domestic Animal Endocrinology 13 453-463

Armstrong JD and Britt JH (1987) Nutritionally-induced anestrus in gilts: metabolic and endocrine changes associated with cessation and resumption of estrous cycles fournal of Animal Science 65 508-523

Armstrong JD, Britt JH and Kracling RR (1986) Effect of restriction of energy during lactation on body condition, enengy metabolism, endocrine changes and reproductive performance in primaparous sows fournal of Animal Science 63 1915-1925

Barb CR (1999) The brain-pituitary-adipocyte axis: role of leptin in modulating neuroendocrine function lournal of Animal Science 77 1249-1257

Barb CR, Cox NM, Matamoros 1A, Kraeling RR and Rampacek GB (1990) Growth hormone (GH) secretion after intracerebroventricular (ICV) administrations of insulin (INS) in the gilt Journal of Animal Science 68 (Supplement 1) 310 (Abstract)

Barb CR, Kraeling RR, Barrelt JB, Rampacek GB, Camphell RM and Mowles TF (1991) Serum glucose and free fatty acids modulate growth hormone and luteinizing hormone secretion in the pig Proceedings of the Society for Experimental Biology and Medicine 198 636-642

Barb CR, Cox NM, Carlton CA, Chang WJ and Randle RF (1992) Growth hormone secretion, serum, and cerebral spinal fluid insulin and insulin-like growth factor-1 concentrations in pigs with streptozotocin-induced diabetes mellitus Proceedings of the Society for Experimental Biology and Medicine $201223-228$

Barb CR, Kraeling RR and Rampacek GB (1995) Glucose and free fatty acid modulation of growth hormone and luteinizing hormone secretion by cultured porcine pituitary cells Journal of Animal Science 73 1416-1423

Barb CR, Kraeling RR and Rampacek CB (1996) Luteinizing hormone and growth hormone (GH) secretion after intracerebroventricular (ICV) administration of IGF-I or insulin (INS) in the prepuberal gilt journal of Animal Science 74 (Supplement 1) 240 (Abstract)

Barb CR, Kraeling RR, Rampacek GB and Dove CR (1997) Metabolic changes during the transition from the fed to the acute feed-deprived state in prepuberal and mature gilts journal of Animal Science 75 781-789

Barb CR, Yan X, Azian M], Kraeling RR, Rampacek GB and Ramsay TG (1998) Recombinant porcine leptin reduced feed intake and stimulates growth hormone secretion in swine Domestic Animal Endocrinology $1577-86$

Barb CR, Barrett JB, Kraeling RR and Rampacek GB (1999) Role of leptin in modulating neuroendocrine function: a metabolic link between the brain-pituitary and adipose tissue Reproduction in Domestic Animals 34 111-125 
Barb CR, Kraeling RR, Rampacek GB and Estienne M) (2000) Current concepts of the onset of puberty in the gilt Reproduction in Domestic Animals (Supplement 6) 82-89

Barb CR, Barrett JB, Kraeling RR and Rampacek GB (2001) Serum leptin concentrations, luteinizing hormone and growth hormone secretion during feed and metabolic fuel restriction in the prepuberal gilt Domestic Animal Endocrinology 20 47-63

Bonneau M (1993) Growth hormone response to GRF and insulin-induced hypoglycemia in Yorkshire and Meishan pigs American Journal of Physiology: Endocrinology and Metabolism 264 E54-E59

Booth PJ (1990) Metabolic influences on hypothalamicpituitary ovarian funclion in the pig fournal of Reproduction and Fertility Supplement 40 89-100

Buonomo FC, Grohs DL, Baile CA and Campion DR (1988) Determination of circulating levels of insulin-like growth factor II (IGF-II) in swine Domestic Animal Endocrinology 5 323-329

Cameron JL, Koerker DJ and Steiner RA (1985) Metabolic changes during maturation of male monkeys: possible sign for onset of puberty American Journal of Physiology 249 E385-E391

Casanueva FF and Dieguez C (1999) Neuroendocrine regulation and actions of leptin Frontiers in Neuroendocrinology 20 317-363

Cosgrove IR and Foxcroft GR (1996) Nutrition and reproduction in the pig: ovarian aetiology Animal Reproduction Science 42 131-141

Cox NM and Britt JH (1988) Pulsatile administration of gonadotropin releasing hormone to lactating sows: endocrine changes associated with induction of fertile estrus Biology of Reproduction 27 1126-1137

Cox NM, Stuart MJ, Althen TG, Bennett WA and Miller HW (1987) Enhancement of ovulation rate in gilts by increasing dietary energy and administering insulin during follicular growth journal of Animal Science 64 507-516

Cox NM, Barb CR, Kesner PJ, Kraeling RR, Matamoros IA and Rampacek GB (1990) Effects of intracerebroventricular administration of insulin on luteinizing hormone in gilts fournal of Reproduction and Fertifity Supplement 4063 (Abstract)

Cox NM, Meurer KA, Carlton CA, Tubbs RC and Mannis DP (1994) Effect of diabetes mellitus during the luteal phase of the oestrous cycle on provulatory follicular function, ovulation and gondatrophins in gilts journal of Reproduction and Fertility 101 77-86

Cunningham MJ, Clifton DK and Steiner RA (1999) Leptin's action on the reproductive axis: perspectives and mechanisms Biology of Reproduction 60 216-222

Dubreuil P, Pelletier G, Petitclerc D, Lapierre H, Couture Y, Brazeau P, Gaudreau P and Morisset J (1987) Influence of age and sex on basal secretion of growth hormone $(\mathrm{GH})$ and on $\mathrm{CH}$-induced release by porcine GH-releasing factor pGRF(1-29NH2) in growing pigs Domestic Animal Endocrinology 4 299-307

Erickson JC, Hollopeter G and Palmiter RD (1996) Attenuation of the obesity syndrome of ob/ob mice by the loss of neuropeptide Y Science 274 1704-1707
Etherton TD and Bauman DE (1998) Biology of somatotropin in growth and laclation of domestic animals Physiologica/ Reviews 78 745-761

Frisch RE (1984) Body íat, puberty and fertility Biological Reviews 59 161-188

Handelsman D1, Spaliviero JA, Scott CD and Baxter RC (1987) Hormonal regulation of the peripubertal surge of insulin-like growth fiactor-1 in the rat Endocrinology 120 $491-496$

Goodman RL (1988) Neuroendocrine control of the ovine estrus cycle. In The Physiology of Reproduction, Vol 1 , pP 1929-1970 Eds E Knobil, JD Neill, LI. Ewing, GS Greenwald, CL Markert and DW Pfaff. Raven Press, New York

Hiney JK, Ojeda SR and Dees WL (1991) Insulin-like growth factor-l: a possible metabolic signal involved in the regulation of female puberty Neuroendocrinology 54 420-423

Kraeling RR and Barb CR (1990) Hypothalamic control of gonadotrophin and prolactin secretion in pigs fournal of Reproduction and Fertility Supplement 40 3-7

Lee CY, Bazer FW, Etherton TD and Simmen FA (1991) Ontogeny of insulin-like growth factors (IGF-I and IGFII) and IGF-binding proteins in porcine serum during fetal and postnatal development Endocrinology 128 2336-2344

Lin J, Barb CR, Matteri RL, Kraeling RR, Chen $X$, Meinersmann RJ and Rampacek CB (2000) Long form leptin receptor mRNA expression in the brain, pituitary and other tissues in the pig Domestic Animal Endocrinology 19 53-61

Lin J, Barb CR, Kraeling RR and Rampacek CB (2001) Developmental changes in the long form leptin receptor and related neuropeptide gene expression in the pig brain Biology of Reproduction 64 1614-1618

Lutz JB, Rampacek GB, Kraeling RR and Pinkert CA (1984) Serum luteinizing hormone and estrogen profiles before puberty in the gilt Journal of Animal Science $\mathbf{5 8}$ 686-69i

Muller EE, Locatelli $V$ and Cocchi D (1999) Neuroendocrine control of growth hormone secretion Physiological Reviews 79 511-607

Pressing A, Dial GD, Esbenshade KL and Stroud CM (1992) Hourly administration of $\mathrm{GnRH}$ to prepubertal gilts: endocrine and ovulatory responses from 70 to 190 days of age Journal of Animal Science 70 232-242

Prunier A and Quesnel H (2000a) Nutritional influences on the hormonal control of reproduction in female pigs Livestock Production Science 63 1-16

Prunier A and Quesnel H (2000b) Influence of the nutritional status on ovarian development in female pigs Animal Reproduction Science 60-61 185-197

Qian H, Barb CR, Compton MM, Hausman GJ, Azain MJ, Kraeling RR and Baile CA (1999) Leptin mRNA expression and serum leptin concentrations as influenced by age, weight and estradiol in pigs Domestic Animal Endocrinology 16 135-143

Rojkittikhun T, Uvnäs-Moberg $K$ and Einarsson S (1993a) Plasma oxytocin, prolactin, insulin and L.H after $24 \mathrm{~h}$ of fasting and after refeeding in lactating sows Acta Physiologica Scandinavica 148 413-419 
Rojkittikhun T, Einarsson S, Zilinskas H, Edqvist LE, it-Uvnäs-Moberg $K$ and Lundeheim N (1993b) Effects of insulin administration at weaning on hormonal patterns and reproductive periormance in primiparous sows Zentralblatt fur Veterinarmedizin Reihe $A \mathbf{4 0}$ , 161-168

Rotwein P, Burgess JD, Milbrandt JD and Krause JE (1988)

- Differential expression of insulin-like growth factor genes in rat central nervous system Proceedings National Academy of Sciences USA 85 265-269

Sara VR and Hall K (1990) Insulin-like growth factors and their binding proteins Physiological Reviews 70 591-614

Spencer GSG, Macdonald AA, Buttle HL, Moore LG and Carlyle SS (1991) Intracerebral administration of insulin-like growth factor I decreases circulating growth hormone levels in the fetal pig Acta Endocrinologica (Copenhagen) $124563-568$

Wade GN, Schneider JE and Li HY (1996) Control of fertility by metabolic cues American fournal of Physiology 270 E1-E19

Werther GA, Abate M, Hogg A ef al. (1990) Localization of insulin-like growth factor-I mRNA in rat brain by in situ hybridization - relationship to IGF-I receptors Molecular Endocrinology 4 773-778

Wetsel WC, Valenca MM, Merchenthaler I, Liposits Z, Lopez Fl, Weiner RI, Mellon PL and Negro-Vilar A (1992) Intrinsic pulsatile secretory activity of immortalized luteinizing hormone-releasing hormonesecreting neurons Proceedings National Academy of Sciences USA 89 4149-4153

Whitley NC, Barb CR, Utley RV, Popwell IM, Kraeling RR and Rampacek CB (1995) Influence of stage of the estrous cycle on insulin-like growth f́actor-I modulation of luteinizing hormone secretion in the gilt Biology of Reproduction 53 1359-1364

Wolverton CK, Azain M), Duffy JY, White ME and Ramsay TG (1992) Influence of somatotropin on lipid metabolism and IGF gene expression in porcine adipose tissue American fournal of Physiology 263 E637-E645

Yamashita S and Melmed S (1986) Insulin-like growth factor I action on rat anterior pituitary cells: suppression of growth hormone secretion and messenger ribonucleic acid levels Endocrinology 118 i76-182 